\title{
Ilman ja liikkeen fenomenologiasta -
}

\section{Ellen Thesleff, Isadora Duncan, Edward Gordon Craig}

\section{Riikka Stewen}

Brasilialaisen taiteilijan Lygia Clarkin työssä Pedra e ar (1966) teokseen osallistuva yleisö kutsutaan ajattelemaan ilmaa ja maan painoa, hengittämään sisään ja täyttämään pienen muovipussin hengitysilmalla, tuntemaan, kuinka kivi, joka on asetettu muovipussin päälle, painuu ilmaa vasten käsien välissä. Teos tekee ilman tuntuvaksi ja maan painon koettavaksi; se näyttää jotain sellaista mitä tavallisesti ei huomata.

Tunnut ja elementit olivat keskeisessä roolissa myös Ellen Thesleffin taiteellisessa työskentelyssä. Esitän että maalaaminen oli Thesleffille elementtien tuntuvuuden, niiden kosketuksen, tavoittelua, ja tarkastelen hänen maalaamalla tapahtuvaa työskentelyään vertaamalla sitä modernin vapaan tanssin edelläkävijän Isadora Duncanin tanssia kos- kevaan ajatteluun. Miten Ellen Thesleff itse ajatteli, siitä tiedämme melko vähän, sillä hän ei oikeastaan koskaan kirjoittanut suoraan maalaamista koskevista ajatuksistaan. Siitä huolimatta on mahdollista rekonstruoida ajattelua, joka tapahtuu itse maalauksissa, ja hahmotella hänen minimalistista fenomenologiaansa. Tulkinnan kiintopisteinä toimivat erityisesti Thesleffin varhaistuotannon Kevätyö (1894; kuva 3 julkaisun sivulla 13) ja viimeisimpiin maalauksiin lukeutuva Aurinkosuudelma (1940-luku), mutta käsittelen myös kirjeitä ja luonnoskirjoja niiltä osin kuin niissä voi tulkita ilmenevän minimalistista fenomenologista ajattelua.

\section{Minimalistinen fenomenologia}

Dominique Janicaud hahmottelee kirjassaan La phénoménologie dans tous ses états minimalistista fenomenologiaa, joka kätkeytyy arkipäivän huomaamattomuuteen. Janicaud kutsuu tätä fenomenologian laatua minimalistiseksi siksi, että sen harjoittaja tietää jo etukäteen, että on mahdotonta selvittää kysymystä kokemuksesta definitiivisesti tai tyhjentävästi. Minimalistinen fenomenologia vertautuu tässä suhteessa taiteeseen. Taide voi tulkita kätkeytyvää ja kääntää sen toiselle kielelle muttei tavoittaa sitä sellaisenaan. ${ }^{1}$ Janicaud korostaa, kuinka Maurice Merleau-Pontyn myöhäisfilosofiassa - joka edustaa eräänlaista minimalistista fenomenologiaa - keskustelukumppaneina ovat taiteilijat ja runoilijat Leonardo da Vincista Paul Cézanneen. Cézanne oli Merleau-Pontylle erityisen merkittävä, ja Merleau-Ponty ammensi monia ajatuksia keskusteluista, joita Cézanne oli käynyt Joachim Gasquet'n kanssa. Etenkin Cézannen ajatukset havaitsemisen geologisista kerroksista vaikuttivat Merleau-Pontyn havaitsemista koskevaan filosofiaan. ${ }^{2}$

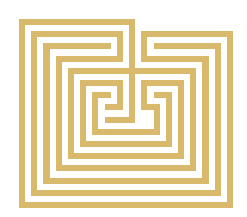


Thesleffin kaksi varhaista työtä täydentävät toisiaan, asettavat tilan ja ilman kysymyksen kahdella toisiaan täydentävällä tavalla. Omakuvassa (1894-1895) tilaa ja kasvoja hahmottavat viivat punoutuvat toisiinsa ja muodostavat nähdyn kerrostumia, jotka limittyvät ja sedimentoituvat. ${ }^{3}$ Kasvot ja tila kietoutuvat yhteen, ja kuva muistuttaa Merleau-Pontyn ajatusta siitä, kuinka havaintokenttäni täyttyy joka hetki heijastuksista, säröistä, ohikiitävistä kosketusvaikutelmista, joita minun on mahdotonta sijoittaa mihinkään tiettyyn havaintoyhteyteen ja jotka siitä huolimatta sijoitan maailmaan, sillä uskon sen niiden lähteeksi. ${ }^{4}$ Kaiku (1891) sen sijaan avaa avaran, miltei rajattoman tuntuisen ilmavan tilan. Maalaus puhuttelee katsojaa kahden tilallisen aistin tasolla: näön ja kuulon, jotka maalauksessa vertautuvat toisiinsa ja tuntuvat määrittävän keskenään samaa tilaa. IImaa ja avaruutta korostaa maalauksessa se, kuinka tytön hahmon pää on kuvattu korkealle puunlatvusten ja taustalla kertautuvien rinteiden yläpuolelle, ilmaan, joka ulottuu joka suunnassa äärettömiin. ${ }^{5}$

Filosofi Luce Irigaray huomauttaa, että ilma on kaikkein unohdetuin elementti länsimaisen ajattelun historiassa, vaikka se kuitenkin on ihmisen ensisijainen asumus, avarampi ja ulottuvaisempi kuin mikään muu. Hän sanoo myös, ettei mikään toinen elementti kuljeta samalla tavalla valoa ja ääntä kuin ilma, joka antaa värin ja ääniaaltojen kulkea lävitseen. IIma on olemassaolon ja maailman ehto, perusta, joka on samaan aikaan pysyvä ja virtaava. ${ }^{6}$

Irigaray pohtii, voiko ilma olla mahdoton ajatella: onko se impensable? IIma ei näyttäydy, se ei tuo itseään esille havaitsemiselle tai ajattelulle: se sallii itsensä tulla unohdetuksi. IIman filosofia onkin ehkä unohdetuin kaikista elementtien filosofioista. Fenomenologian perustaja Edmund Husserl ajatteli kokemuksien horisontin, elämismaailman, jäävän arkiselta inhimilliseltä havainnolta ja tietoisuudelta sitä enemmän kätköön mitä perustavampaa se on - on kuvaavaa, että hän ei edes ajatellut ilmaa kokemismaailman perustana. Irigaray kysyy, onko olemassa keinoja, joilla ilma tulee ajateltavissa olevaksi; millä transformaatioilla ilma voi tulla näkyväksi? ${ }^{7}$

Irigaraylaisittain tulkittuna Ellen Thesleffin taiteellisesta työskentelystä muodostuu transformaatio-oppi, tekniikka, joka näyttää ilman elementin, sen kosketuksen ja tunnun, al- kaen varhaisesta omakuvasta ja päätyen myöhäistuotannon Aurinkosuudelmaan.

Tarkastelen seuraavassa keinoja ja metodeja, joita Ellen Thesleffin työskentely käyttää, hänen teoksissaan tapahtuvaa minimalistista fenomenologiaa.

\section{Kevätyö 1894}

Kun Kevätyön (1894) nimellä tunnettu maalaus oli ensimmäistä kertaa esillä, kriitikot kiinnittivät huomiota maalauksen hohtavaan valohämyyn. Jac. Ahrenberg kirjoitti siitä, kuinka kaikki maalauksissa "verhoutuu samanlaiseen hopeanväriseen valoon, jossa on kalpeita ilmavia varjoja, hienovaraisia valopälviä", ja kuinka "kaikki on kyllästetty valolla, jonka alkuperästä ei pääse selvyyteen mutta joka silti on oikealla paikallaan". ${ }^{8}$

Maalaus kuvaa keväistä järvenrantamaisemaa; sen vasemmalla reunalla voi etualalla hahmottaa koivujen tai haapojen talven jäljiltä paljaita runkoja. Jos puissa on lehtiä, ne ovat vielä pieniä ja hiirenkorvalla - maiseman piirteet eivät niinkään ole maalauksen aiheena kuin valohämy ja vedenpinnan peiliefekti. Maalauksen luoma tilavaikutelma on erikoinen, hopeinen peilinkaltainen maalauspinta tekee mahdottomaksi tarkentaa 
katsetta yksityiskohtiin tai orientoitua maalauksen tilassa: taivas heijastuu vedessä, vesi taivaassa. Veden elementti kaksinkertaistaa ja peilaa ilmaa: tekee ilman näkyväksi.

Ilma peilautuu veteen ja tulee näkyväksi peilikuvassaan - ilma, joka itsessään kätkeytyy kokemismaailman perustavana ulottuvuutena, muuttuu havaittavaksi heijastuessaan veden syvyyteen. Maalaus toteuttaa metodia, transformaatiota, jonka avulla mahdotonta-ajatella voi ajatella ja unohtuvan ilman elementin voi nähdä. Kevätyö kuvaa, kuinka valon täyttämä ilma on totaalinen ympäristö, kuinka "kaikki" on kyllästetty valolla, jonka lähdettä ei voi havaita - kuten Jac. Ahrenberg koki maalauksen.

Kevätyössä ilma tulee ajateltavaksi - se ei enää katsomisen hetkellä ole impensable, mahdoton ajatella.

\section{Ilma: Eetteri - Energia - Anemos}

Kevätyössä ilma kuljettaa erityisesti valoa. Thesleffin 1890-luvun aikalaiset ajattelivat ilmaa eetterinä, se oli energiaa ja aaltoja. Langaton lennätin, röntgensäteet, radio kaikki nämä keksinnöt kertoivat aikalaisille siitä, kuinka ilma kuljetti värähtelyä ja erilai- sia aaltoja: ilma oli liikkeen elementti. ${ }^{9}$ IIma oli medium, jossa myös psyykkiset energiat kulkivat ja välittyivät. Telekinesis ja telepatia olivat tieteellisen kiinnostuksen kohteina, ja vielä vuonna 1910, jolloin Wassily Kandinskyn Taiteen henkisestä sisällöstä ensimmäistä kertaa ilmestyi, Kandinsky oli varma siitä, että tunteensiirrosta muodostuisi taiteen keskeinen keino: lähitulevaisuudessa tunteet siirtyisivät telepatian avulla taiteilijalta katsojalle ilman että materiaalisia teoksia enää tarvittaisiin. ${ }^{10}$

Myös Cézanne, jonka minimalistinen fenomenologia inspiroi Merleau-Pontya, ajatteli ilmaa perustavana, auringonvalon läpäisemänä, ympäristönä. Cézanne puhui auringonvalon suodattumisesta, siitä kuinka valosta tulee materiaalista ja se inkarnoituu, läpäisee kaiken maailmassa, tavalla, jonka voi ajatella Merleau-Pontyn näkyvyyden lihan, la chair du visible, lähtökohdaksi. Cézanne pohti, voisiko tätä perustavaa suhdetta valon täyttämään ilmaan mitenkään kertoa tai kuvata - samalla tavoin kuin Irigaray myöhemmin kysyi, voiko ilmaa edes ajatella vai onko se mahdoton-ajatella. ${ }^{11}$

Irigarayn jälkeen amerikkalainen tieteenfilosofi Karen Barad on kvanttifysiikka lähtökohta- naan korostanut, kuinka mikään ei ole erillistä ja kuinka ääriviivoja ei todellisuudessa ole olemassa: mikään ei ole tyhjää vaan täyttyy hiukkasista, jotka koskettavat toisiaan, limittyvät toisiinsa, kietoutuvat lakkaamatta toisiinsa. ${ }^{12}$

Baradin tavoin amerikkalainen filosofi Kelly Oliver on tähdentänyt, ettei ilma ole tyhjää vaan täyttyy energiasta: "[...] sähköisestä energiasta, kemiallisesta energiasta, lämpöenergiasta, mekaanisesta energiasta, valokimppujen energiasta, magneettisesta energiasta." 13

Oliverille näkemistä ja havaitsemista ylipäänsä on mahdollista ajatella energian kohtaamisena ja vastaanottamisena. ${ }^{14}$ IIma, valo ja energian eri muodot ovat mediumeja, keinoja tai väliaineita, jotka liittävät meidät havaitsevina olentoina maailmaan; vain energian kiertokulku mahdollistaa havaitsemisen ja ajattelemisen: olemisen. ${ }^{15}$ Energian liike ja kierto liittää kaiken maailmassa yhteen; se on myös perusta maailmasuhteelle, missä mikään mitä maailmassa kohdataan ei ole toista tai vastatusten vaan yhtä kanssani.

Universaali yhteenkuuluvuus ja siitä kumpuava etiikka olivat itse asiassa 1800-luvun lopun ja 1900-luvun ensimmäisen vuosikym- 
menen estetiikan keskeisiä ajatuksia, joihin kuului optimistinen usko siihen, kuinka luonnontieteiden edistyminen tulisi todistamaan todeksi mystiikan eri traditioiden käsityksen kaiken yhteenkuuluvuudesta ja siitä, kuinka kaikki materiaalisessa, koettavassa maailmassa on hengen läpäisemää: kuinka universaali hengitys yhdistää olennot ja asiat toisiinsa.

Myös filosofi Félix Ravaisson, Aristoteleen tuntija, jakoi käsityksen universaalista solidaarisuudesta. Hänelle sen perustana oli liike ja anemos - tuuli, hengitys, henki, ilman liikahdus - joka läpäisee kaiken. Kaikella millä on kyky liikkua on kyky hengittää ja tuntea; kaikki mihin voi vaikuttaa - kaikki mikä on olemassa - kuuluu universaalin solidaarisuuden, universaalin hengityksen piiriin; kasvi tai kivi ei ole sekään ulkopuolella. ${ }^{16}$ Ravaissonin oppilas Henri Bergson sanoi Ravaissonista, että tämän ajattelun perustana oli näkemys ykseydestä, joka yhdistää kaikkea olevaa epäorgaanisesta aineesta kasveihin, kasveista eläimiin, eläimistä inmisiin. ${ }^{17}$

\section{Painovoima: Universumin tanssi}

IIma, energiana ja kosketuksena, tuulenhenkäyksenä ja liikahduksena, on Thesleffin maalausten teema, johon 1900-luvun ensimmäisellä ja toisella vuosikymmenellä ilmestyy uudenlainen ulottuvuus, kun ilma elementtinä antaa hänen maalauksissaan tilaa myös maalle, painovoimalle ja kiertoliikkeelle. Liike on nyt materiaalista liikettä - se on liikettä, joka kuvautuu painavina ja paksuina maalikerroksina, jotka on levitetty palettiveitsellä. ${ }^{18}$ Se on samaan aikaan myös liikettä suhteessa painovoimaan ja maan pysyvyyteen. ${ }^{19}$ Hanna-Reetta Schreck on esittänyt, että tähän aikaan Thesleff kiinnostui liikkeestä ja laajemmin inmisten ruumiillisesta suhteesta ympäristöönsä, ja kuvannut, kuinka Tytöt (Tytöt niityllä) -maalaus tuo tämän painovoiman uuden teeman selkeästi esiin vuonna 1906. ${ }^{20}$

Kesällä 1909 Forte dei Marmissa Thesleff kirjoittaa kuuntelevansa maan sydämenlyöntejä. ${ }^{21}$ Kun hän 1900- ja 1910-luvulla ajatteli liikettä, hän ajatteli sitä suhteessa maan sykkeeseen ja painovoimaan, samalla tavalla kuin uuden vapaan tanssin puolestapuhuja Isadora Duncan. ${ }^{22}$ Duncanin luento tulevaisuuden tanssista The Dance of the Future/Der Tanz der Zukunft oli julkaistu kirjana sekä englanniksi että saksaksi vuonna 1903.
Thesleff oli myös saattanut vuoden 1904 tienoilla nähdä Duncanin tanssivan Münchenissa, jonne hänen sisarensa Thyra oli muuttanut opiskelemaan 1903 ja josta Duncanin todellinen Euroopan valloitus samana vuonna alkoi. Kun Duncan esiintyi Helsingissä Venäjän kiertueensa yhteydessä alkuvuodesta 1908, kaikissa lehdissä julkaistiin monisivuisia artikkeleita hänen esityksistään ja ajattelustaan samoin kuin kouluista, joita hän oli perustanut, ensiksi Berliiniin Grünewaldiin 1904. Alkuvuonna 1908 Thesleff oli kuitenkin Italiassa, joten Helsingin esityksiä hän ei nähnyt. Joka tapauksessa Duncan oli oman aikansa kuuluisuus, jota haastateltiin lehtiin kaikkialla ja jonka vaikutukselta saattoi olla vaikea välttyä, etenkin kun hän liitti tanssin myös naisten vapautumiseen, ja hänen ajatuksensa kiinnostivat erityisesti ajan radikaaleja taiteilijoita ja teatterintekijöitä, Mihail Fokinista Konstantin Stanislavskiin. Itse asiassa Duncan valitsi esiintymispaikoikseen nimenomaan taiteelle omistettuja tiloja, Lontoossa hän esiintyi New Galleryssa, Münchenissä Künstlerhausissa; hän ei pitänyt itseään tanssijana vaan taiteilijana. ${ }^{23}$

Duncan ajatteli, että tanssi on universumin liikkeen tulkitsemista ja sen välittämistä; 
tanssijan inhimillisen mediumin kautta koko universumin rytmi siirtyy ja välittyy katsojille. ${ }^{24}$ Duncanilainen tanssi on kehollisen ja rytmillisen maailmasuhteen tulkintaa, kokemuksen minimalistista fenomenologiaa.

Tanssin ja uskonnon tutkija Kimerer Lamothe on tulkinnut Duncanin tekstejä suhteessa siihen mitä tämä itse tuo esiin tanssin, uskonnon ja filosofian suhteesta. Kuten monille vuosisadan vaihteessa, myös Duncanille taide ja uskonto olivat yhtä: uudistamalla tanssia, lähteille palaamalla, hän ajatteli - kuten Lamothe korostaa - voivansa uudistaa uskonnon ja rituaalin, luoda uuden uskonnon, jossa kehollisuus ja aistillisuus on samaan aikaan henkeä. ${ }^{25}$ Duncan osallistui teksteillään ja esitelmillään vuosisadanvaihteen keskusteluihin, joissa hengen ja aineen vastakkaisuus kyseenalaistettiin. ${ }^{26}$

Duncan etsi universaalin liikkeen lähtökohtia myös antiikista. Hän piti kreikkalaisiin maljakkomaalauksiin kuvattuja rituaaleja ja tansseja ainutkertaisena lähteenä, jonka avulla saattoi saada tietoa luonnollisesta liikkeestä. Hänen tarkoituksensa ei ollut kopioida tai jäljitellä, sillä hänen mielestään antiikin tanssien rekonstruointi olisi yhtä hyödytöntä kuin mahdotontakin; hän sanoi, että tanssin on oltava oman aikansa taidetta, se voi syn- tyä vain aikansa tunteista ja vuosisatansa elämästä - samalla tavoin kuin kreikkalaisten tanssi syntyi heidän elämästään ja tunteistaan. ${ }^{27}$ Tähän hän sai ehkä inspiraation vuonna 1896 Pariisissa ilmestyneestä piirroksin ja kronofotografisin kuvin havainnollistetusta tutkielmasta La danse grecque antique d'après les monuments figurés. Teoksen kirjoittaja säveltäjä Maurice Emmanuel vertasi antiikin Kreikan tanssia oman aikansa klassiseen balettiin ja uskoi, että maalakkomaalaukset olivat tarkkoja dokumentteja: kreikkalaiset maalarit olivat tallentaneet tanssin katoavat liikkeet yhtä tarkasti kuin valokuvakamera. ${ }^{28}$

\section{Ensimmäinen liike}

Paluu antiikkisille lähteille oli eräs $1900-l u-$ vun alun modernistisista virtauksista. ${ }^{29}$ Klassistinen modernismi tulkitsi traditiota uudella tavalla ja vetosi antiikkiin etsiessään ja hahmotellessaan toisenlaisia elämisen muotoja kuin mitä teollinen kapitalismi tuotti. Taiteenuudistajat kiinnostuivat samalla tavalla "paluusta lähteille" kuin fenomenologian perustaja Husserl. Taiteen alkuperän ajateltiin löytyvän tanssista ja rituaalista, mikä osaksi johtui myös Friedrich Nietzschen vaikutuksesta, sillä Nietzsche oli muuttanut kuvan hillitystä seesteisestä antiikista, kun hän Tragedian synnyssä kirjoitti apollonisen ja dionyysisen kaksoissidoksesta tanssin ja taiteen lähteillä. Thesleffin ja Magnus Enckellin yhteinen ystävä Yrjö Hirn pohti myös alkuperäisintä ilmaisumuotoa, joka hänellekin oli tanssi. ${ }^{30}$

Duncan kutsui Tragedian syntyä raamatukseen ja kuljetti Nietzschen toista teosta Niin puhui Zarathustra aina mukanaan. Nietzsche oli Duncanille tanssin filosofi, sillä Nietzschen kirjoitukset olivat hänelle täynnä lauseita inmisen tanssivasta, tanssillisesta, olemisesta kuten hän sanoi. ${ }^{31}$ Duncanin tulkinnassa tanssi kollektiivisena rituaalina oli keskeisessä roolissa, kun Nietzsche pyrki kumoamaan länsimaiden filosofisen tradition platonismin ja palauttamaan aistillisuuden ja kehollisuuden arvon. Kollektiivinen tanssi merkitsi kehollisen kokemuksen jaettavuutta antiikin tragedioiden kuoro-osuuksissa ja Dionysokselle omistettujen rituaalien yhteisöllisessä hurmiossa. ${ }^{32}$

Duncanille tanssi merkitsi maailmankaikkeuden liikkeen siirtämistä inhimilliseen skaalaan. Inhimillisen mediumin, tanssijan, kautta luonnon ja koko universumin liike välittyy katsojille: tanssi on kuin rukous, rituaali, jonka osallistujat tulevat osaksi sfäärien 
ikuista liikettä. Siksi Duncan etsi myös "ensimmäistä liikettä" - liikkeen minimalistista fenomenologiaa. ${ }^{33}$

Ensimmäinen liike oli Duncanille olennaisesti universaalia liikettä. Femina-lehden haastattelussa vuonna 1914 hän kuvasi käsityksenään, että kaikkein perustavin liike on aaltoliikettä: äänestä ja valosta lähtien kaikki liike on aaltoliikettä. ${ }^{34}$ Liike - kyky liikkua ja tulla liikutetuksi - on hänellekin universaalin solidaarisuuden perusta. Tanssija - liikkuva nainen - oli linkki liikkeen ketjussa, joka läpäisee universumin. ${ }^{35}$

Liikkeen jatkuvuus ensimmäisestä liikkeestä alkaen oli Duncanille niin tärkeää, ettei hän sallinut esitystensä tallentamista elokuvan keinoin. Tässä suhteessa hän ajatteli samoin kuin Évolution créatrice -teoksen Bergson, jolle kinematografinen liike ei ollut uutta luovaa liikettä vaan pysähdytettyjen hetkien peräkkäinen sarja. Duncanin elokuvaa koskevan kiellon vuoksi hänen tanssiesityksiään ei ole dokumentoitu liikkuvan kuvan keinoin, sen sijaan niitä on kuvattu lehtiartikkeleissa, kirjeissä ja päiväkirjoissa sekä monien taiteilijoiden piirustuksissa.

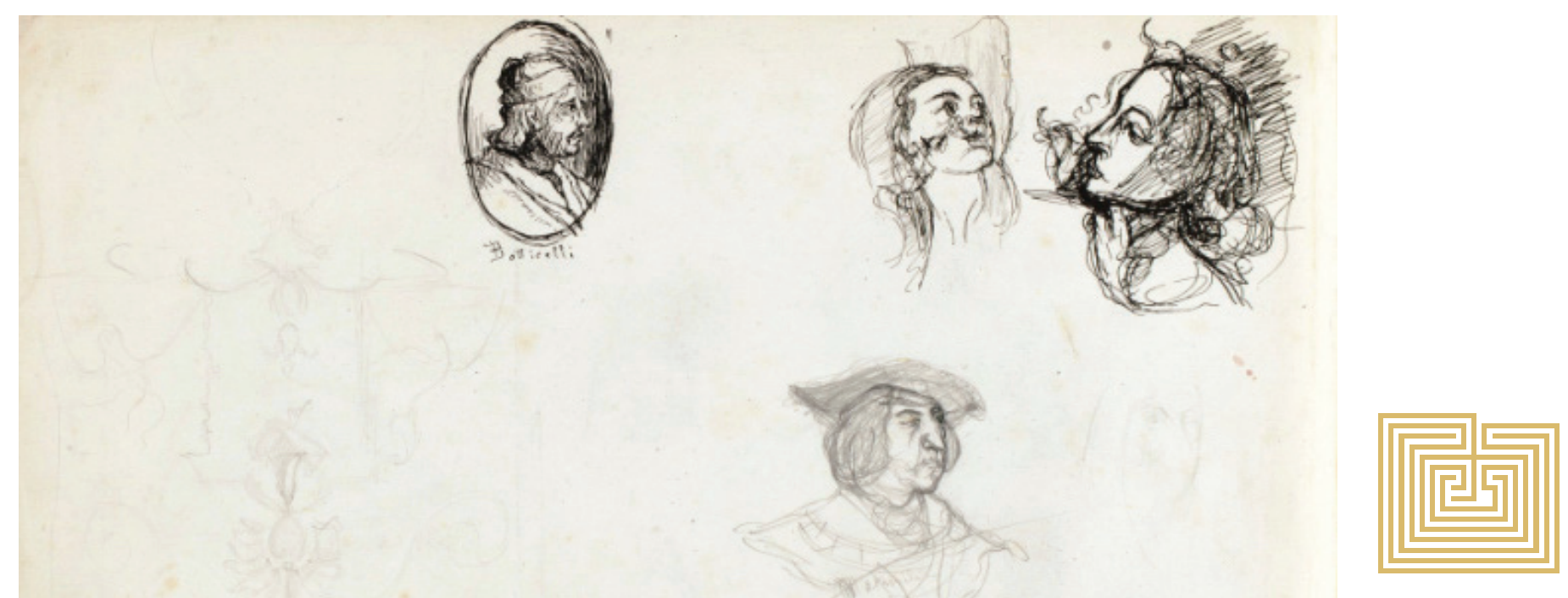

\section{Primavera}

Tanssintutkija Gabriele Brandstetter on Poetics of Dance -teoksessa korostanut, kuinka 1900-luvun alkupuolen moderni tanssi ilmen-
Kuva 1. Ellen Thesleffin luonnoskirjasta Inv. A IV 3449:12. Luonnoskirja 1891-1894, Ateneum. 
si kolmenlaista arkkityyppistä affektimuotoa. Hän nimesi affektimuodot kreikkalaisten esikuvien mukaan Nikeksi, menadiksi ja Primaveraksi. Brandstetter soveltaa arkkityyppien tulkintaan Nietzschen inspiroiman taidehistorioitsija Aby Warburgin ajatusta tunnemuodoista, Pathosformel. Warburgille tietyt antiikkiset kuvatyypit kantoivat mukanaan niihin kiteytyneitä affekteja, jotka varhaisrenessanssin aikaan aktivoituivat uudelleen, ja tarjosivat väyliä tunteiden kanavoimiseksi. ${ }^{36}$

1900-luvun alussa myös tanssitaiteilijat hahmottivat Warburgin tavoin arkkityyppistä liikettä varhaisrenessanssin maalausten kautta. Botticellin Primavera oli maalaus, joka inspiroi Duncania. ${ }^{37}$ Sen keskushahmo, Neitsyt Mariaan vertautuva Afrodite, oli lähtökohtana Duncanin esiintymiselle paljain jaloin, kevyissä liehuvissa, liikettä jatkavissa asuissa.

Duncan itse kertoo elämäkerrassaan rakastaneensa lapsesta lähtien Botticellin maalausta, jonka jäljennöksen hänen äitinsä ripusti seinälle aina heidän muuttaessaan uuteen kotiin. Jos soveltaa Duncanin omaa ajatusta kuvien ja taiteen vaikutuksesta kasvavaan lapseen, on ajateltava, että hän koki Primaveran ja erityisesti siinä kuvatun liik- keen muuttuneen osaksi identiteettiään. Hän kuvaa, kuinka maalauksessa ruoho alkoi kasvaa, tuuli liikuttaa oksia hänen silmissään - nykytanssin käsittein puhuttaisiin kinesteettisestä empatiasta ja mielikuvituksesta. ${ }^{38}$

Eräs Duncanin koreografioista oli omistettu Primaveralle. Thesleffien arkistossa on säilynyt ohjelmalehtinen Münchenin Künstlerhausin esityksestä, jossa Primavera oli yhtenä numerona mukana.

Primavera oli Thesleffille tärkeä kiintopiste jo ennen kuin hän saattoi nähdä Duncanin tansseja. Ensimmäisen Firenzen kautensa aikana 1894 hänellä oli Primaveran jäljennös huoneensa seinällä. ${ }^{39}$ Toisin kuin Duncan Thesleff katsoi maalauksessa erityisesti oikealla olevaa hahmoa, jota yleensä pidetään Florana. Thesleff hahmotteli luonnoskirjaansa Primaverasta vain Floran pään ja kasvit, joita Flora hengittää. Pieni piirrosmerkintä kertoo siitä, kuinka Thesleff kiinnitti huomiota erityisesti ilmaan ja hengitykseen, anemokseen. ${ }^{40}$

Duncanille Primavera oli koreografian lähtökohta, Thesleffille maalausten teema. Floran hahmo näyttäytyy vielä myöhemminkin monissa Thesleffin 1930-luvun maalauksissa, joille hän on antanut nimeksi Kevät.
Eräässä voi nähdä myös kukan, kasvin, joka pulppuaa hengityksen tavoin kevättä symboloivan hahmon suusta.

\section{Antiikin jumalat: Edward Gordon Craig}

A god dances through me. - Isadora Duncan

Jag målar som en gud. — Ellen Thesleff

Thesleffiä ja Duncania yhdisti eräs seikka: Edward Gordon Craig, Duncanin ensimmäisen vuonna 1906 syntyneen lapsen isä ja Thesleffin ystävä vuodesta 1906 tai 1907 alkaen. Craigille Duncan ei oikeastaan koskaan ollut kuollut; hän jatkoi keskustelua Duncanin kanssa kirjoittamalla huomautuksia, repliikkejä, vielä tämän postuumisti 1927 ilmestyneen elämäkerran marginaaliin. ${ }^{41}$ Craig tunnetaan teatterin uudistajana, joka halusi luopua psykologisesta, kirjallisesta teatterista, ja tuoda yksilöllisyyden sijaan teatteriin takaisin uudenlaisen version antiikin näytelmien kuorosta sellaisena kuin se oli Euripidesta edeltävällä ajalla. Myös Duncan ajat- 
teli esiintyessään olevansa kuoro, ei koskaan solisti. ${ }^{42}$ Kuoron tärkeys heidän ajatuksissaan oli peräisin Nietzschen tragediaa koskevasta käsityksestä. Kreikkalainen teatteri oli olennaisesti kollektiivista, osallistuvaa; Duncan itse olisi mieluiten aina esiintynyt paikassa, jossa katsojat voivat osallistua rituaaliin.

Craigille teatteri tarkoitti kollektiivista, ylipersoonallista rituaalia. Liike oli tässä teatterissa tärkeää, mutta liikkeen laatu olisi ollut jotakin muuta kuin Duncanin tanssissa Craig ei koskaan toteuttanut uuden teatterin näkemystään konkreettisesti. Teatterikoulussa, jonka Craig Duncanin esimerkkiä seuraten suunnitteli perustavansa Lontooseen, oppilaille olisi aivan ensimmäiseksi hankittu liikkeen malliksi fasaaneja, tiikereitä ja joutsenia. ${ }^{43}$

Antiikin jumalat eivät Craigille, Duncanille tai Thesleffille koskaan kadonneet kokemuspiiristä. Vielä paljon myöhemmin, kahden maailmansodan jälkeen, Craig kirjoitti Thesleffille vuoden 1949 syksyllä syyskuun 10. Tourette-sur-Loup'n kylästä (Alpes-Maritime) läheltä Nizzaa Etelä-Ranskasta:

Ihailen ja ihmettelen näitä LINTUJA - PÄÄSKYJÄ. Athene-jumalar muutti hahmonsa pääskyksi, kun hän auttoi Odysseusta. Pääskyt ovat nyt menneet Afrikkaan - 300 000 000 vuotta (\& ehkä vielä joitakin vuosia sen päälle) sitten Jumala määräsi pääskyt lähtemään Afrikkaan syyskuun ensimmäisenä päivänä (tai sen tienoilla) ja siitä saakka ne ovat totelleet. ${ }^{44}$

Craig oli lukenut Homeroksen Odysseusta uutena englanninnoksena ja kirjoittanut jo melkein vuotta aiemmin Thesleffille siitä kuinka Odysseus oli suurin kirja mitä hän tiesi: " - se on IHME. [Homeros] antaa väkevän tupauksen ilmoituksen siitä, kuinka henget \& Jumalan lähetit ovat päivittäin keskuudessamme - naamioituneina." ${ }^{45}$

Antiikki - mielikuvat kreikkalaisuudesta Nietzschen ja toisaalta Botticellin välittäminä - inspiroi niin Duncanin kuin Thesleffin työskentelyä samalla tavalla kuin se oli lähtökohtana Craigille. Thesleffin töissä 1910-luvulta lähtien liikkuvat erilaiset antiikkiset ja klassiset hahmot - niin kuin myös hänen läheisen kollegansa Magnus Enckellin maalauksissa 1890-luvulta lähtien. ${ }^{46}$ Tulenpalvoja, Meduusa, Ikaros, vuoden- ja vuorokaudenaikojen personifikaatiot Pekkalan kartanon seinämaalauksissa ovat vain joitakin näistä antiikin jälkikuvista Thesleffin tuotannossa. Tulenpalvojan kaltaisten arkkityyppisten liikehahmojen merkitys oli keskeinen myös Thesleffin liikettä kuvaavissa töissä samalla tavoin kuin modernissa tanssissa.

Duncanin kirjoitusten ja esitysten suoranaista vaikutusta Thesleffin ajatteluun ei ole mahdollista arvioida, vaikka voikin osoittaa, että esimerkiksi Duncanin usein koreografioima Chopinin valssi on aiheena monissa Thesleffin teoksissa. Thesleffillä on tekstien ja muistikuvien lisäksi saattanut olla käytössään suosittuja valokuvia Duncanista, joissa tämä poseeraa müncheniläisessä Studio Elvirassa vuonna $1903 .{ }^{47}$ Tavoitteenani on kuitenkin lähinnä ollut osoittaa liikkeen merkitys universaalina solidaarisuutena kummankin - ja hieman myös Craigin - taiteellisessa työskentelyssä ja katsoa sitä minimalistisen fenomenologian avaamasta näkökulmasta. ${ }^{48}$

Voi kuitenkin todeta, että kun Craig kirjoitti Thesleffin taiteesta pseudonyymillä Lontoossa julkaistuun The Beau -lehteen, hän puhui tämän Pallopeli -teoksesta käsittein, jotka tuntuvat olevan peräisin Duncanin ajattelusta. Craig korostaa erityisesti sitä, kuinka Thesleff tavoittaa liikkeen ja saa teoksen katsojan "tuntemaan maan rytmin." 49 


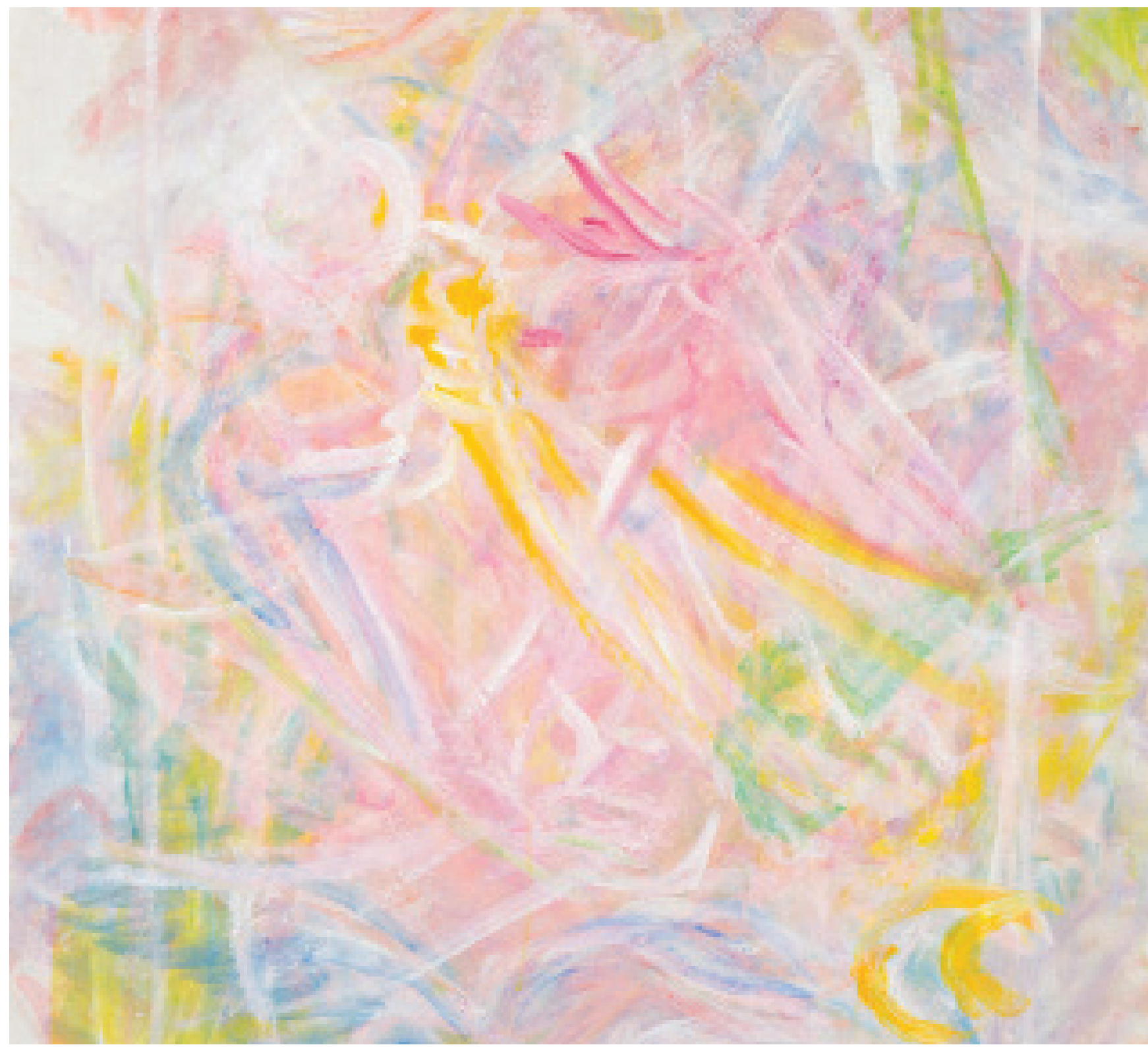

Kuva 2. Ellen Thesleff, Aurinkosuudelma, 1940-I. Öljymaalaus, 88 x $75 \mathrm{~cm}$. Kuva: Hagelstam, http://www.hagelstam.fi/media/ catalog/product/cache/1/image/9df78eab33525d08d6e5fb$8 d 27136 \mathrm{e} 95 / 5 / 2 / 52$ 68.jpg 
Aurinkosuudelma: Elementtien kohtaaminen

Kaikille kolmelle taiteilijalle ilma oli täynnä energiaa ja liikettä: universumin liikettä, vaIon ja äänen aaltoilua, näkymättömien jumalien toimintaa. Jos Thesleff 1900-luvun ensimmäisen ja toisen vuosikymmenen aikana etsi keinoja tavoittaa tätä energiaa kuvaamalla liikettä suhteessa maan vetovoimaan, niin myöhemmissä töissä väri on hänelle paikka, jossa kaikki liike tapahtuu. Thesleff kirjoitti muistikirjaansa vuonna 1917 "ainoastaan väri, ei muuta kuin väri, väri = liike" ja etsi maalauksissaan liikettä, joka syntyisi väristä. ${ }^{50}$ Väri on efemeraalinen - vaihtuva, väreilevä, muutosta ja liikettä itsessään.

Merleau-Pontyn myöhäistuotannossa väri merkitsi ulkoisen ja sisäisen maailman kohtaamista, paikkaa, jossa ne läpäisevät toisensa: näkyvän kudosta, jossa subjekti ja objekti eivät ole erillisiä vaan ikään kuin kosketuksessa. Värin minimalistinen filosofia vertautuu siksi ilman fenomenologiaan.

Myöhäiskauden Kevät -aiheissa näyttäytyy Thesleffin liikettä koskevan ajattelun synteesi, jossa väri, värillisyys maailman kudoksena, hallitsee kaikkea. Aurinkosuudelmassa subjektin ja maailman rajat ovat täydellisesti liuenneet, kaikki on kosketusta, yhtä yhteistä näkyvän kudosta, universumin hengitystä. Filosofi Jean-Luc Nancy on korostanut, kuinka kosketuksen tuntu edellyttää koskevan ja kosketetun keskinäistä läpäisevyyttä, kummankin kykyä tulla affektoiduksi. Koska aistiva sielu kuuluu itsekin aistittavaan maailmaan, se tuntee itsensä jokaisessa aistimuksessa. Nancyn mukaan kosketusaistissa tämä vastavuoroisuus on kaikkein ilmeisintä, mutta se määrittelee kaikkia aisteja periaatteessa samalla tavoin: koskettava ja kosketettu ovat läpikotaisin toisiinsa kietoutuneita. ${ }^{51}$ Aurinkosuudelman voi nähdä myös maalauksellisena kuorona, sulautumisena kollektiivisen rituaalin aistillisuuteen tai kohtaamisena auringon kanssa, josta Cézanne puhui auringon inkarnoitumisena maailmaan kauttaaltaan, l'incarnation du soleil à travers le monde. ${ }^{52}$

Isadora Duncan ajatteli elementtien kosketusta - auringonvaloa, sadetta, sumua myös jumalien metamorfooseina ja eroottisina kohtaamisina. Hänelle liike oli maailmaa animoivan universaalin rakkauden liikettä:

Muinaisten kreikkalaisten myyteissä rakkauden akti ilmaistiin aina jumalan muodonmuutoksena joksikin elementiksi. Zeus ilmeni Semelelle valonsäteenä, Danaelle kultasateena,
Euroopalle härän, Ledalle valkoisen joutsenen muodossa. Nämä muodonmuutokset tar koittavat pohjimmiltaan rakkauden liikkeen koittavat pohjimmiltaan rakkauden likkeen
muotoja, sen symboleja. Ne ovat rakkauden todellista tanssia - kaikki luonnossa on osallista rakkauden elementistä ja vastaavasti sen elementistä siksi tulee pilvi, usva, tuli, härkä tai valkoinen joutsen. ${ }^{33}$

Aurinkosuudelma kuvaa myös kohtaamista auringon kanssa; myytti keväästä, Botticellin Primaveran jälkikuva, näkyy siinä vihreiden siveltimenvetojen muistumana keskellä kaiken läpäisevää inkarnoitunutta auringonvaloa. IIma on kauttaaltaan värillistä: koskettava ja kosketettu läpäisevät toisensa ilman elementissä, joka maalauksessa on näkyvää ja silti edelleen mahdoton-ajatella, samalla tavoin kuin Duncanin pilvi tai usva universaalin rakkauden elementtinä.

Dominique Janicaud'n minimalistista fenomenologiaa tulkiten Duncan ja Thesleff transformoivat, kääntävät teoksissaan toiselle kielelle ilman tunnun ja universaalin energian: tanssi ja maalaus tulkitsevat sitä mikä on mahdoton-ajatella. Thesleffin varhaisessa Kaiku -maalauksessa ilman atmosfääri ilmenee rajattomana tilan avaruutena, Kevätyössä peiliefekti on transformaatio, jonka tekee ilman näkyväksi. Aurinkosuudelmassa taas ilma itsessään kuvautuu värillisenä energia- 
na, joka läpäisee kaiken. (Pallopeli -teoksen eri versiot sen sijaan tulkitsevat maan ja painovoiman fenomenologiaa; näistä kolmesta taiteilijasta Thesleffin Pallopelistä kirjoittanut Craig on painovoiman tulkki.) Duncanin tansseissa kosminen aaltoliike kulkee tanssijan kautta ja skaalautuu koreografian havaittaviksi liikkeiksi.

Duncanille tanssija on liikkeen medium ja liike tarkoittaa osallisuutta universaalista liikkeestä, joka läpäisee ja koskettaa kaikkea mikä on. Thesleffille väristä tulee liikkeen ja kosketuksen medium. Teoksissaan Duncan ja Thesleff etsivät keinoja tehdä näkyväksi havainnolta ja ajattelulta kätkeytyvää, niitä edeltävää, avoimuutta, maailmassa olemisen mahdollisuusehtoa. Irigaray kutsuu tätä mahdollisuusehtoa ilmaksi ja muistuttaa, että ilma ei ole objekti objektien joukossa: se on elementti, jota hengitämme. IIma ei ole tyhjää vaan täynnä väriä ja aaltoliikettä: atmosfääri, jossa kaikki kietoutuu yhteen, havaintoa perustavampaa ja fundamentaalisempaa avoimuutta maailmalle.

\section{Viitteet}

1 Dominique Janicaud, La phénoménologie dans tous ses états (Paris: Éditions de l'Éclat, 2009 [1990]), 270.

2 Janicaud, La phénoménologie dans tous ses états, 270.

3 Omakuvaa ovat tulkinneet Marja Lahelma, Ideal and Disintegration: Dynamics of the Self and Art at the Fin-de-Siècle (Helsinki: Unigrafia, 2014), 148-179 ja Hanna-Reetta Schreck, Minä maalaan kuin jumala: Ellen Thesleffin elämä ja taide (Helsinki: Teos, 2017), 119-122.

4 Dominique Janicaud viittaa Havaitsemisen fenomenologian johdantoon, Janicaud, $L a$ phénoménologie dans tous ses états, 268.

5 Asta Kihlman kirjoittaa Kaiku-maalauksesta ja Ekhon teemasta, myös Thesleffin Ekho-runosta, väitöskirjassaan Kolme tutkielmaa sukupuolesta: Identiteettipolitiikka Beda Stjernschantzin, Sigrid af Forsellesin ja Ellen Thesleffin taiteessa (Turku: Turun yliopiston julkaisuja Sarja - ser. C osa - tom 457, Scripta Lingua Fennica Edita, 2018), 169-173.

6 Luce Irigaray, L'oubli de l'air chez Martin Heidegger (Paris: Minuit, 1983), 15.

7 Irigaray, L'oubli de l'air, 17. Myös Petri Berndtson tarkastelee ilman ja hengityksen fenomenologiaa $\mathrm{mm}$ Irigaray lähtökohtanaan väitöstutkimuksessaan Phenomenological Ontology of Breathing: The

Phenomenologico-Ontological Interpretation of the Barbaric Conviction of We Breathe Air and a New Philosophical Principle of Silence of Breath, Abyss of Air (Jyväskylä: University of Jyväskylä, 2018).

8 Nya Pressen 14.10. 1894.

9 Linda Dalrymple Henderson, "Vibratory Modernism: Boccioni, Kupka, and the Ether of Space" teoksessa From Energy to Information: Representation in Science and Technology, Art, and Literature, ed. Linda Dalrymple Henderson \& Bruce Clarke (Stanford, California: Stanford University Press, 2003), 126-149.

10 Voi myös muistaa, että Ellen Thesleffin sukupolvelle sähkön näkymätön energia ei ollut luonnollistunut osaksi kulttuuria vaan sähkövalo koettiin uutuutena, se ei suinkaan ollut Thesleffin lapsuuden Kuopion kaupunkivalaistus. Kun hän näkee ensimmäistä kertaa sähkövalon, hän kirjoittaa sisarelleen, kuinka sähkövalo muistuttaa kuutamoa. Ellen Thesleff Gerda Thesleffille syyskuussa 1884, Svenska Litteratursällskapet, arkisto 958.

11 Joachim Gasquet, Cézanne (Paris, 1927 [1921]), Deuxième partie, Les motifs, 136.

12 Karen Barad, Meeting the Universe Halfway: Quantum Physics and the Entanglement of Matter and Meaning (Durham: Duke University Press, 2007), 153-155. Barad viittaa fyysikko Richard Feynmaniin ja toisaalta kolonialismin kriitikko Gayatri Chakravorty Spivakiin. Baradille kyse on ajattelutavasta, jota hän kutsuu agentiaaliseksi realismiksi ja joka korostaa intra-aktiota, havaitun ja havaitsevan keskinäistä vuorovaikutusta sekä sitä kuinka inminen on kietoutuneena osaksi ilmiöitä, joita luonnontieteet havainnoivat, ja konstituoituu tässä vuorovaikutuksessa. 2000-luvun alkupuolella Jane Bennett on myös korostanut kaiken materian elävyyttä kirjassaan Vibrant Matter: A Political Ecology of Things (Durham: Duke University Press, 2010).

13 Kelly Oliver, "Witnessing Subjectivity" teoksessa Ipseity and Alterity: Interdisciplinary Approaches to Intersubjectivity, ed. Shaun Gallagher \& Stephen Watson (Rouen: Publications de l'Université de

Rouen et du Havre, 2004), 194. Hänen luetteloonsa kuuluu "[e]lectrical energy, chemical energy, thermal energy, mechanical energy, photic energy or light, magnetic energy".

14 Oliver, "Witnessing Subjectivity", 196: "Vision, like other types of perception, is a response to energy, specifically differences in photic energy."

15 Oliver, "Witnessing Subjectivity", 194: "Air, light and various forms of energy are the mediums through which we experience the world. We are connected to the world through the circulation of energy that enables our perception, thought, language, and life itself." 
16 Félix Ravaisson, Testament philosophique (Paris: Éditions Allia, 2008).

17 Henri Bergson, La vie et l'oeuvre de Ravaisson. La pensée et le mouvant (Paris : Presses universitaires de France, 1938, 259-291. François Laruelle on kutsunut Ravaissonin ajattelua nontranssendentaaliseksi ontologiaksi varhaisessa teoksessaan Phénomène et différence: Essai sur l'ontologie de Ravaisson (Paris: Klincksieck, 1971) 18 Kukka Paavilainen, "Veitset - Ellen Thesleffin vapauden välineet" teoksessa Ellen Thesleff - Värien tanssi, toim. Hanna-Reetta Schreck ja Ilkka Karttunen ([Punkaharju:] Taidekeskus Retretti, 2008).

19 Fenomenologian perustaja filosofi Edmund Husserl huomautti myös, että luonnollinen elämismaailma eroaa matemaattisten idealisaatioiden maailmasta siinä, että maa on inhimillisessä kokemuksessa se mihin kaikki liike suhteutuu ja mihin nähden liike tapahtuu. Elämismaailmassa maa mielletään itse liikkumattomaksi, vaikka

kopernikaanisen tieteellisen käsityksen mukaan maapallo on itse liikkuva taivaankappale. Juha Himanka, "Husserl's Argumentation for the PreCopernican View of the Earth", The Review of Metaphysics, Vol 58, No 3 (March 2005), 621-644. 20 Schreck, Minä maalaan kuin jumala, 155-156. 21 Ibid., 190.

22 Thyran Münchenin opiskeluajasta kertoo ibid., 145-148.

23 Duncan, My Life, 92. Duncanin Manner-Euroopan valloitus alkoi nimenomaan Münchenistä vuonna 1902. Hanna-Reetta Schreck ja Asta Kihlman sekä myös Monica Schalin Åbo Akademissa 2004 hyväksytyssä väitöskirjassaan ovat kaikki korostaneet sitä, kuinka Thesleff suomalaisista taiteilijoista parhaiten tunsi Münchenin uusimpia taidesuuntauksia esimerkiksi Kandinskyn Phalanx-ryhmän ympärillä. Duncan esiintyi yleensä nimenomaan taidekontekstissa, Münchenissa Künstlerhausissa; omaelämäkerrassaan Duncan kertoo, kuinka taivutteli esiintymistään vastustaneen Franz von Stückin puolelleen
24 Isadora Duncan, The Dance of the Future/Der Tanz der Zukunft (Leipzig: Verlag Eugen Diederichs 1903), 13.

25 Kimerer Lamothe, "'A God Dances Through Me': Isadora Duncan on Nietzsche's Revaluation of Values". The Journal of Religion, Vol 85, No 2 (April 2006), 241-266.

26 Esimerkiksi Duncan, The Dance of the Future, 26.

27 Isadora Duncan, My Life (New York: Liveright Publishing / W.W. Norton \& Company, 2013), 53-54. 28 Maurice Emmanuel, La danse grecque antique d'après les monuments figurés (Paris: Librairie Hachette et Cie, 1896), 25-26.

29 Musiikin ja tanssin tutkimuksessa kiinnostavia uusia näkökulmia avaavia tutkimuksia on Samuel Dorf, Performing Antiquity: Ancient Greek Music and Dance from Paris to Delphi 1890-1930 (New York and Oxford: Oxford University Press, 2018), joka kirjoittaa eheyttävästä, reparatiivisesta, luennasta, jolle tunnusomaista on kosketus ja kiintymys, Eve Kosofsky Sedgwickia seuraten, 154. Kuvataiteessa 1900-luvun alkupuolen uusklassism monine "kreikkalaisuuden" muotoineen on lähes tutkimaton aihe; musiikissa tutkitumpi Stravinskyn klassinen kausi on viime vuosina saanut kiinnostavan kontekstuaalisen tulkinnan, kun Tamara Levitz julkais Stravinskyn Ida Rubinsteinille 1934 säveltämästä

Perséphone-teoksesta mikrohistoriallis-genealogisen laajan tutkimuksen Modernist Mysteries: Perséphone (Oxford \& New York: Oxford University Press,

2012). Perséphonen teksti oli André Giden, jonka oli työstänyt aihetta 1890-luvulta alkaen. Myös Duncan luki Sapfoa, Ovidiuksen Metamorfooseja, Pierre Louÿsin Chansons de Bilitis'tä ja esitti näihin kreikkalaisiin teemoihin pohjautuvia tansseja kreivitär Greffulhen salongissa - elämäkerrassaan hän vakuuttaa, ette lainkaan käsittänyt niiden homoeroottista sävyä. Kreikkalaisuudesta ja seksuaalisista identiteeteista on kirjoittanut Juha-Heikki Tihinen, Halun häilyvät rajat: Magnus Enckellin teosten maskuliinisuuksien ja feminiinisyyksien representaatioista ja itsen luomisesta (Helsinki: Taidehistorian seura, 2008). 30 Yrjö Hirn, Konstens ursprung: En studie öfver den estetiska värksamhetens psykologiska och sociologiska orsaker (Helsingfors: Söderströms, 1902).

31 Isadora Duncan, The Art of The Dance (New York: Theatre Books, 1928), 142.

32 Duncan, My Life.

33 Ibid., 62. Duncanin työskentelyyn liittyi paljon tutkimusta, Bibliothèque Nationalessa ja Oopperan kirjastossa hän luki kaiken tanssista ja totesi loppujen lopuksi hyväksyvänsä vain kolme mestaria: Rousseaun, Nietzschen ja Walt Whitmanin. (Ibid., 65). 34 Femina-lehden haastattelusta 1.4.1914 teoksessa Écrits sur la danse (Paris: Grenier, 1927), 68. 35 Ann Cooper Albright lainaa nämä lauseet Duncanin esseestä The Dancer and Nature (1928) artikkeliinsa "The Tanagra Effect" teoksessa

Macintosh, Fiona (ed.), The Ancient Dancer in the Modern World: Responses to Greek and Roman Dance (Oxford \& New York: Oxford University Press, 2010).

36 Gabriele Brandstetter, Poetics of Dance: Body, Image, and Space in the Historical Avantgardes (New York, NY: Oxford University Press, 2015).

37 Katso esimerkiksi Duncan, My Life, 95.

38 Ibid., 95.

39 Ellen Thesleffin kirje Gerdalle Firenzestä keväällä tai kesällä 1894, Svenska Litteratursällskapet, arkisto 958.

40 Luonnoskirjasta, Inv. A IV 3449:12 Luonnoskirja 1891-1894, Ateneum.

41 Christopher Innes, Edward Gordon Craig: A Vision of Theatre (Abingdon: Routledge, 1998), 116. Duncan oli eronnut Craigista pian heidän yhteisen lapsensa Deirdren syntymän jälkeen ja lähtenyt kiertueelle Venäjälle. Duncan menehtyi tapaturmaisesti 1927, ennen omaelämäkerran julkaisemista, Craig eli vuoteen 1966 saakka.

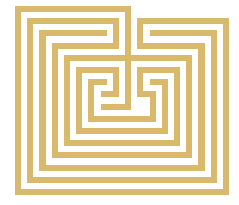


42 Duncan, The Art of The Dance, 96.

43 Harry Kessler, Journey to the Abyss: The Diaries of Count Harry Kessler 1880-1918, ed. Laird M.

Easton (New York; Vintage Books/Random House, 2013), 566-567. Päiväkirjamerkintä on Lontoosta vuoden 1911 marraskuussa. Craigin suunnitellun koulun johtokunta oli päättänyt hankkia fasaaneja, tiikereitä ja joutsenia, joita havainnoimalla oppilaat opiskelisivat äänetöntä ja kaunista liikettä.

44 Svenska Litteratursällskapet, arkisto 958.

Alkuperäinen teksti: I have great wonder about these BIRDS - SWALLOWS. It was into a swallow that the Goddess Athene changed herself while helping Odysseus. The swallows have now gone away to Africa - 300,000,000 years ago (\&maybe a few years more) the swallows were told by the God to go to Africa on (about) September 1st, \& since that time they have obeyed $-[$.

45 " - it's a MARVEL He gives us a powerful promise announce of the spirits being daily here with us disguised: \& of the agents of God disguised. One believes him more than any other - as for the men \& women Penelope! Odysseus. Circe as woman. \& men of low station in life \& grand...." Kirje on kirjoitettu Le Cannet'sta 14.12.1948, oikeinkirjoitus ja neljä pistettä Craigin. Svenska Litteratursällskapet, arkisto 958. 46 Riikka Stewen, "Rakkauden kehissä: Magnus Enckellin mytologiat" teoksessa Juha-Heikki Tihinen, toim., Magnus Enckell, (Helsinki: Helsingin kaupungin taidemuseo, 2000).

47 Studio Elviran olivat perustaneet 1887 Anita Augspurg ja Sophia Goudstikker. Studio Elviran Duncanista ottamista kuvista, Isadora Duncan 18771927: Une sculpture vivante (Paris: Paris musées: Musée Bourdelle, 2009), 47-57.

48 Hanna-Reetta Schreck on käsitellyt Pallopeli/ Forte dei Marmi -aihetta, joka toteutui maalauksena ja puupiirroksena Craigin The Mask -lehteen,

Schreck, Minä maalaan kuin jumala, 191. Thesleffien arkistossa on säilynyt pieni vedos, jonka voi kuvitella Thesleffin ja Craigin keskustelunaiheeksi Cafe
Reininghauseniin, jossa Thesleff vietti paljon aikaa ja jossa lähes kaikki hänen Firenzen kirjeensä on kirjoitettu. Craig on kirjoittanut siihen: I like this - it is you. Craigille Thesleff oli - ainakin tässä vaiheessa - painovoiman ja maan, viivan, taiteilija, jonka töissä kuitenkin oli Debussy'n musiikin kaltaista lyriikkaa niin kuin hän kirjoitti - hän ei nähnyt Thesleffiä värin taiteilijana. Craigin sukupuolittavaa sanastoa tässä yhteydessä on kiinnostavaa verrata Harri Kalhan tulkintaan Magnus Enckellin värimaalauksen kriittisesta vastaanotosta, Tapaus Magnus Enckell (Helsinki: SKS, 2005).

49 [Edward Gordon Craig], The Beau, London, 1910.

50 Svenska Litteratursällskapet, arkisto 958.

51 "Since Aristotle, we have known that the identity of the sensible and the sentient in feeling or sensing (which is thus a being-felt or being-sensed as well), similar to the identity of the thinkable and thought in the act of thinking, implies at the focus of the sensation (in vision, hearing, olfaction, gustation and contact) a kind of compenetration of both, in the act and as this act. The act of sensation, which is to say, Energeia according to Aristotle's concept of act, constitutes actual effectiveness, the event being produced by the sensation. The sentient sou is itself sensible and for this reason feels itself as it feels. And nowhere is this clearer (nowhere is it more sensed) than in the sense of touch: not the eye, nor the ear, nose or mouth, feel themselves feeling with the intensity and precision that the skin feels." J-L Nancy, "Rühren, Berühren, Aufruhr. Stirring, Stirring up, Uprising", teoksessa Gabriele Brandstetter, ed., Touching and Being Touched: Kinesthesia and Empathy in Dance and Movement (Boston: De Gruyter, 2013), 16.

52 Gasquet, Cézanne, Deuxième partie, Les motifs, 136.

53 Femina, Avril 1, 1914.
FT, dos. Riikka Stewen on taidehistorioitsija, nykytaiteen tutkija ja kirjoittaja, joka toimii tällä hetkellä yliopistonlehtorina

Turun yliopistossa. Hänen tutkimusaiheensa käsittelevät $\mathbf{m m}$. taiteen filosofiaa sekä modernin ja nykytaiteen kysymyksiä. Hän on toiminut myös kriitikkona ja kääntäjänä sekä koonnut näyttelyitä.

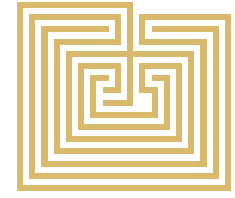

